\title{
Clay Pipes from the Tuck Carpenter Site (41CP5) Camp County, Texas
}

Jesse Todd

Unknown

Robert L. Turner

Follow this and additional works at: https://scholarworks.sfasu.edu/ita

Part of the American Material Culture Commons, Archaeological Anthropology Commons, Environmental Studies Commons, Other American Studies Commons, Other Arts and Humanities Commons, Other History of Art, Architecture, and Archaeology Commons, and the United States History Commons

Tell us how this article helped you.

This Article is brought to you for free and open access by the Center for Regional Heritage Research at SFA ScholarWorks. It has been accepted for inclusion in Index of Texas Archaeology: Open Access Gray Literature from the Lone Star State by an authorized editor of SFA ScholarWorks. For more information, please contact cdsscholarworks@sfasu.edu. 


\section{Clay Pipes from the Tuck Carpenter Site (41CP5) Camp County, Texas}

Creative Commons License

(c) (i) (8)

This work is licensed under a Creative Commons Attribution-NonCommercial 4.0 International License 


\title{
ClAY PIPES FROM THE TUCK CARPENTER Site (41CP5) CAMP CounTy, TEXas
}

\author{
Jesse Todd and Robert L. Turner
}

\begin{abstract}
In this paper, four clay elbow pipes are described from the Tuck Carpenter site (41CP5) in Camp County, Texas, and compared to clay pipes from other areas.
\end{abstract}

\section{Introduction}

The Tuck Carpenter site (41CP5) is located approximately 3.19 miles east of downtown Pittsburg and overlooks Dry Creek in Camp County, Texas. The site consists of at least 45 Caddo interments that date to the Titus phase. The site yielded a calibrated 2 sigma radiocarbon age of A.D. 1473-1635 (Perttula 2005:Table 112). Based upon the presence of a stemmed, Caddo-produced ceramic chalice or goblet from Grave 33, Turner postulated that the cemetery's terminal date may be a few years past the de Soto expedition, which was lead by Moscoso into Texas in 1542. Turner (1978) was able to divide the burials into two components, Early and Late. Perttula (1992:112), however, was able to determine that three subphases were present.

During the excavation of the burials, seven clay elbow pipes were recovered (Turner 1978:73), four of which are in Mr. Robert Turner's possession. The pipes are from Graves 15, 23, 25, and 26. In this paper, the pipes are described and compared to pipes from other sites in northeastern Texas as well as other states.

\section{Discussion}

The measurements for the pipes are presented in Table 1. The location where the measurements of the pipes were taken is presented in Figure 1. The pipes are shown in Figures 2 and 3.

Table 1. Clay elbow pipe measurements (in mm).

$\begin{array}{llllll}\text { Grave } & \text { a } & \text { b } & \text { c } & \text { d } & \text { e } \\ \mathbf{1 5} & 36 & 36 & 32 & 25 & 15.5 \\ \mathbf{2 3} & 50 & 37.5 & 31.5 & 26 & 16 \\ \mathbf{2 5} & 50 & 34 & 28.5 & 23.5 & 17.5 \\ \mathbf{2 6} & 44 & 39 & 31 & 30 & 18\end{array}$

\section{Chronology}

Perttula (1992:248-249) compared the presence of arrow point and pottery types from Titus phase cemeteries in the Cypress Creek Basin. Based upon the co-association of specific arrow/pottery types, he was able to divide the Titus phase in the Cypress Creek Basin into three temporal periods with several subphases. At the Tuck Carpenter site, Period 2 consists of subphases a and b, which range in age from ca. A.D. 1450 to 1600. Bassett and Maud arrow points are the major arrow types, while a variety of pottery types such as Wilder Engraved and Ripley Engraved are present at that time. Period 3, subphase c at the site belongs to the "Classic" Titus phase and probably dates after ca. A.D. 1600. Talco and Maud arrow points characterize this period, especially the Talco type. 


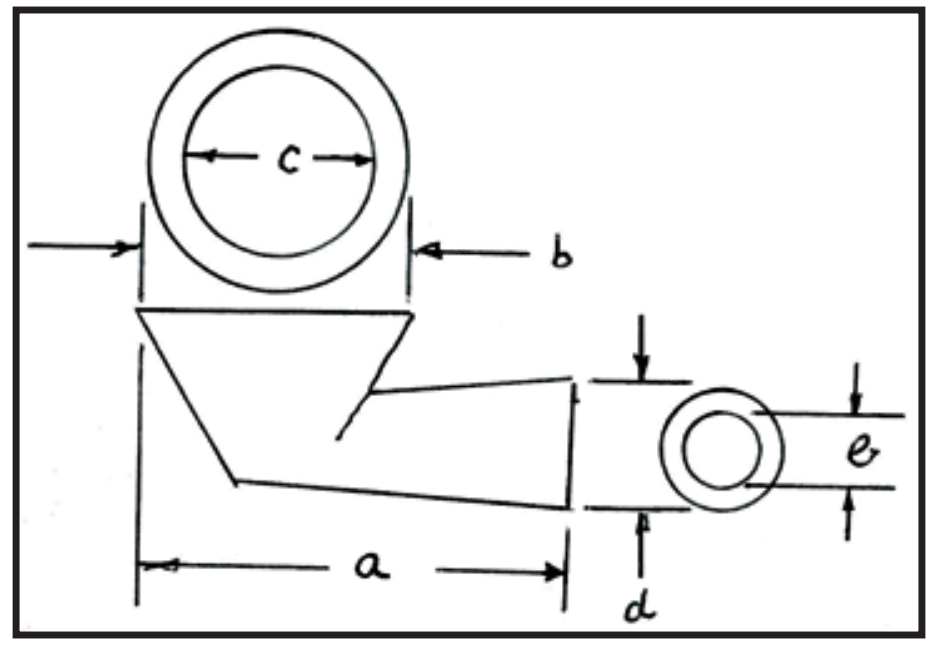

Figure 1. Location of pipe measurements.

Table 2. Arrow and pottery types and periods and subphases associated with pipes (Turner 1992; Perttula 1992:112).

\begin{tabular}{|c|c|c|}
\hline Grave & Arrow and Pottery Types & eriod/subphase \\
\hline 15 & $\begin{array}{l}4 \text { Ripley Engraved bowls, } 1 \text { Maydelle Incised vessel, } \\
3 \text { Perdiz arrow points }\end{array}$ & $2, \mathrm{a}$ \\
\hline 23 & $\begin{array}{l}3 \text { Ripley Engraved carinated bowls, } 2 \text { Ripley Engraved } \\
\text { compound bowls, } 1 \text { La Rue Neck Banded vessel, } 1 \text { Avery } \\
\text { Engraved Red bottle, } 2 \text { Ripley Engraved jars, a square } \\
\text { Ripley Engraved vessel, } 7 \text { Maud arrow points, } 8 \text { Perdiz } \\
\text { arrow points, } 7 \text { Basset arrow points }\end{array}$ & $2, \mathrm{~b}$ \\
\hline 25 & $\begin{array}{l}3 \text { Ripley Engraved carinated bowls, } 2 \text { Ripley Engraved } \\
\text { Compound bowls, Wilder Engraved bottle, } 2 \text { Talco arrow } \\
\text { points, } 1 \text { Perdiz arrow point }\end{array}$ & $3, \mathrm{c}$ \\
\hline 26 & $\begin{array}{l}2 \text { Ripley Engraved carinated bowls, } 2 \text { Bullard Brushed } \\
\text { vessels, } 1 \text { Avery Engraved vessel }\end{array}$ & Unknown \\
\hline
\end{tabular}

\section{Comparisons with Other Sites}

Biconical and keeled pipes are found throughout the Caddo area in Arkansas (Moore 1909; Wood 1981), Louisiana (Moore 1909; Jones 1984) and Oklahoma (Wyckoff 1979; Finkelstein 2000). In Texas, Jackson (1933) provides an overview of pipes from East Texas but there are numerous other sites containing both styles of pipes. Keeled elbow pipes retain some of the characteristics of the Red River pipes (Hofman 1967:10). The projecting stem edge of the Red River pipe was turned up to join the distal end of the bowl, and in some cases, the keel was highly conventionalized.

More specifically, the biconical pipe shown in Figure 2B is similar to an elbow pipe recovered from the Roitsch site (41RR16) in Burial 30 in Red River County, Texas (Perttula 2008:373). The pipe also is similar to one found at the Keno Place site in Louisiana (Moore 1909:128). The slightly angular pipe illustrated in Figure 2A closely resembles a pipe found in Burial 4 at the Horton site (41CP20) in Camp County, Texas (Hunt et al. 1996:F-11).

Although a specific keeled elbow pipe comparable to the one from Grave 25 (Figure 3B) was not found in the literature, a pipe similar to the one in Figure 3A is illustrated from Bowie County, Texas by Biggs and Malone (1970:Figure 65). 

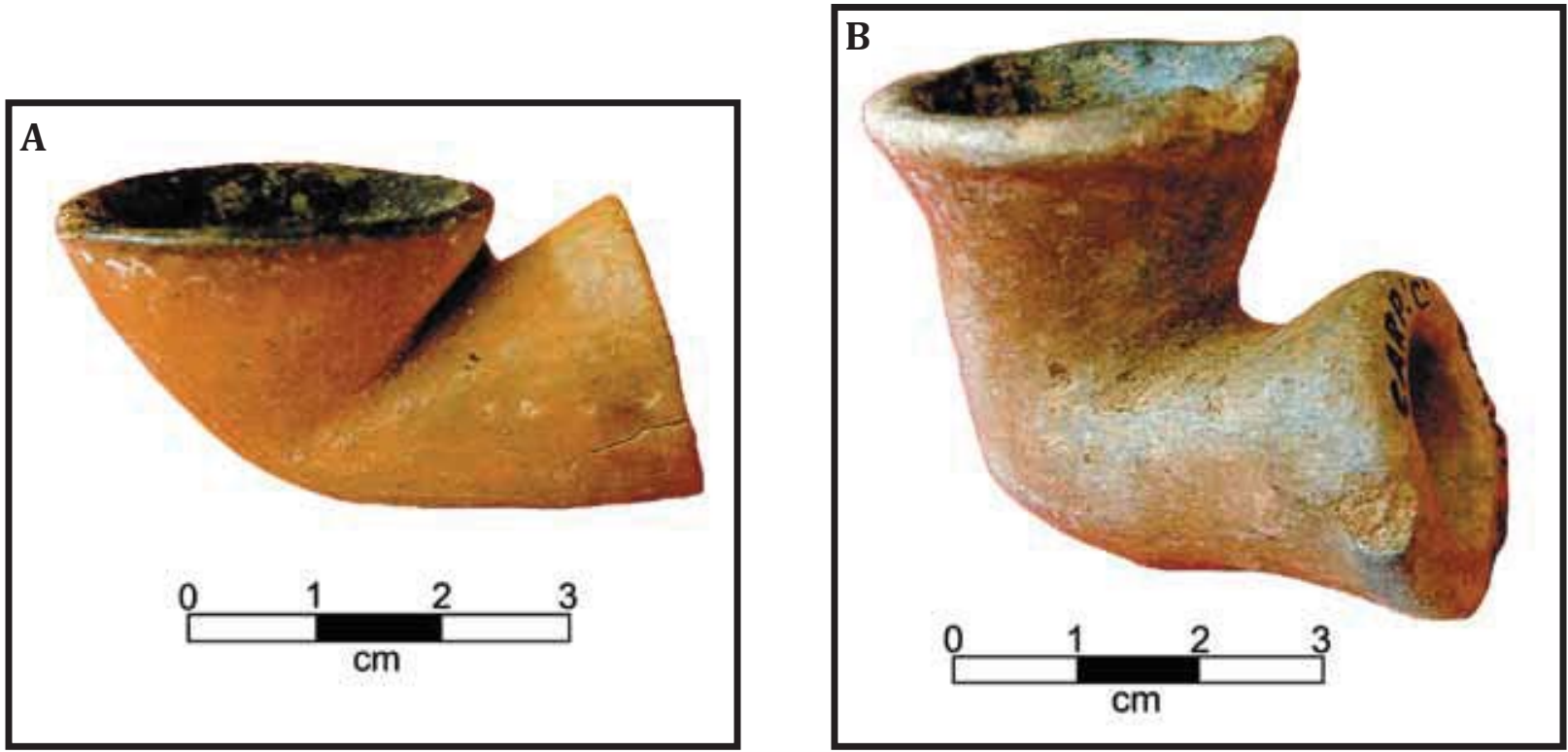

Figure 2. A) Slightly angular elbow pipe from Grave 15. B) Biconical pipe from Grave 26.
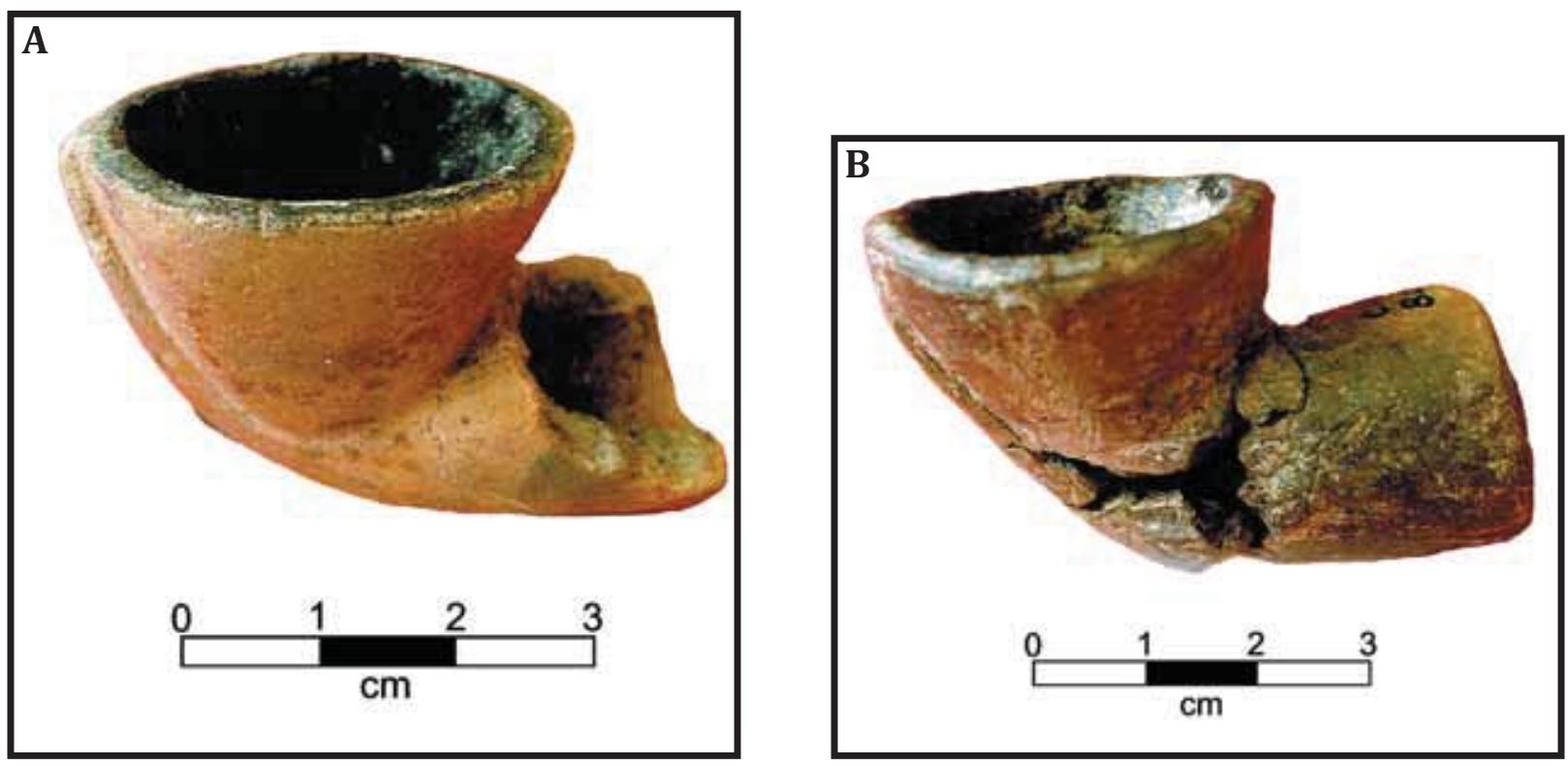

Figure 3. A) Keeled elbow pipes from Grave 23. B) from Grave 25 at site 41CP5.

\section{Conclusions}

Pipes found at the Tuck Carpenter site (41CP5) probably range in age from ca. A.D. 1450 to the post1600s. With such a time span, pipes could have been traded from or copies made from any of the above discussed sites.

\section{Acknowledgments}

I want to thank Dr. Timothy Perttula for reviewing several versions of this paper. 


\section{References Cited}

Briggs, Alton K. and James M. Malone

1970 An Archeological Survey of the Texarkana Reservoir. Report on the First Season. Archeological Survey Report Number 7, Texas Historical Survey Committee and Texas Water Development Board, Austin.

Finkelstein, J. Joe

2000 The Norman Site Excavations near Wagoner, Oklahoma. Caddoan Archeology 11(1-2):6-22.

Hoffman, Michael P.

1967 Ceramic Pipe Style Chronology along the Red River Drainage in Southwestern Arkansas. The Arkansas Archeologist 8(1):4-14.

Hunt, Steven M., Floyd D. Largent, Jr. and Maynard B. Cliff

1996 Cultural Resources Evaluation of the Pilgrim's Pride Property South of Big Cypress Creek, Camp County, Texas. Miscellaneous Reports of Investigations, Number 118, Geo-Marine, Inc., Plano.

Jackson, A. T.

1933 Indian Pipes of East Texas. Bulletin of the Texas Archeological and Paleontological Society 5:69-86.

Jones, Reca Bamburg

1984 The Panola Plantation Site: A Plaquemine Burial Mound in Northeast Louisiana. Louisiana Archaeology Society 11:139-163.

Moore, Clarence B.

1909 Antiquities of the Ouachita Valley. Journal of the Philadelphia Academy of Natural Sciences. XIV:1170.

Perttula, Timothy K.

1992 "The Caddo Nation" Archaeological \& Ethnohistoric Perspectives. University of Texas Press, Austin.

2005 Synthesis of the Archeology of the Pilgrim's Pride Site (41CP304). In Archeological Investigations at the Pilgrim's Pride Site (41CP304), a Titus Phase Community in the Big Cypress Creek Basin, Camp County, Texas. Vol. I, edited by T. K. Perttula, pp. 357-413, Reports of Investigations No. 30, Archeological \& Environmental Consultants, LLC, Austin.

2008 The Archeology of the Roitsch Site (41RR16), an Early to Historic Caddo Period Village Site on the Red River in Northeast Texas. With contributions by J. E. Bruseth, J. W. Cogswell, G. M. Colby, S. M. Derrick, G. J. Fritz, M. D. Glascock, S. E. Goldborer, W. A. Martin, H. Neff, D. G. Steele and B. C. Yates. In Collected Papers from Past Texas Archeological Summer Field Schools. T. K. Pertulla, Editor, pp. 313-628, Special Publication No. 5, Texas Archeological Society, Austin.

Turner, Robert L.

1978 The Tuck Carpenter Site and its Relation to Other Sites within the Titus Focus. Bulletin of the Texas Archeological Society 49:1-110.

1992 Prehistoric Mortuary Remains at the Tuck Carpenter Site, Camp County, Texas. Studies in Archeology 10, Texas Archeological Research Laboratory, The University of Texas at Austin.

Wood, Raymond W.

1981 The Poole Site, 3GA3. The Arkansas Archeologist 22:7-64.

Wyckoff, Don G.

1970 Archaeological and Historical Assessment of the Red River Basin in Oklahoma. In Archeological and Historical Resources of the Red River Basin. Edited by H. A. Davis, pp. 66-134, Research Series No. 1, Arkansas Archeological Survey, Fayetteville. 